\title{
Promising features of Moringa oleifera oil: recent updates and perspectives
}

\author{
Muhammad Nadeem ${ }^{1 *}$ and Muhammad Imran²
}

\begin{abstract}
Lipids are the concentrated source of energy, fat soluble vitamins, essential fatty acids, carriers of flavours and many bio-active compounds with important role in maintaining physiological functions of biological body. Moringa oleifera is native to Himalaya and widely grown in many Asian and African countries with seed oil content range from $35-40 \%$. Moringa oleifera oil (MOO) has light yellow colour with mild nutty flavour and fatty acids composition suggests that $\mathrm{MOO}$ is highly suitable for both edible and non-edible applications. MOO is extremely resistant to autoxidation which can be used as an antioxidant for the long term stabilization of commercial edible oils. Thermal stability of MOO is greater than soybean, sunflower, canola and cottonseed oils. High oleic contents of MOO are believed to have the capability of increasing beneficial HDL cholesterol and decreased the serum cholesterol and triglycerides. MOO applications have also been explored in cosmetics, folk medicines and skin care formulations. Overall, this review focuses on commercial production status, food applications, antioxidant characteristics, health benefits, thermal stability, fractionation, cholesterol contents, medicinal, nutraceutical action, toxicological evaluation, biodiesel production, personal care formulations and future perspectives of the $\mathrm{MOO}$ for the stake holders to process and utilize $\mathrm{MOO}$ as a new source of edible oil for industrial purpose.
\end{abstract}

Keywords: Moringa oleifera oil, Fatty acid profile, Antioxidant activity, Oxidative stability, Industrial applications

\section{Background}

Researchers are trying to find out the new and nontraditional sources of foods to feed the ever increasing human population. The diminishing resources of foods, particularly, edible oils and fats have necessitated to explore the potential of existing sources of edible oils. Fats and oils are the important part of diet in almost every civilization of the world. They are used in cooking, frying and baking etc. From nutritional point of view, fats and oils play an important role in body. They are the concentrated source of energy, fat soluble vitamins, essential fatty acids, carriers of flavours and many bio-active compounds, which are necessary for many physiological functions [1]. Dietary guidelines suggest that about $30 \%$ of the total caloric requirements should be fulfilled from fats and oils [2]. Moringa oleifera Lam (Drum Stick) is native to Himalaya and widely grown in many Asian and African countries [3]. Oil contents of the seeds range from $35-40 \%$ (Table 1) while the

\footnotetext{
* Correspondence: muhammad.nadeem@uvas.edu.pk

${ }^{1}$ Department of Dairy Technology, University of Veterinary and Animal

Sciences, Lahore, Pakistan

Full list of author information is available at the end of the article
}

application of enzyme technology can further improve the recovery of oil from seeds using the orthodox oil extraction techniques [4]. In contrast to soybean, sunflower, canola, corn and cottonseed oil, Moringa oleifera oil (MOO) is extremely resistant to auto-oxidation [5, 6]. Fatty acids and triglyceride composition of oil suggests that $\mathrm{MOO}$ is highly suitable for both edible and non-edible applications (Table 2) [7]. Chemical characterization of oil revealed that free fatty acids, moisture content, refractive index, iodine value, peroxide value and colour unit (Lovibond Tintometer Scale) were $0.22,0.17 \%, 1.452,65.7 \mathrm{cg} / \mathrm{g}, 0.24$ $\left(\mathrm{meqO}_{2} / \mathrm{kg}\right)$, melting point $19.2{ }^{\circ} \mathrm{C}$ and Red 1.5 and 15 yellow (Table 3) [8]. MOO has light yellow colour, with pleasant nutty flavour. Electronic nose analysis also revealed the mild nutty flavour, resembling to peanuts, which was also evidenced by the overlapping of many chromatograms [9]. Due to pleasant nutty flavour, lower levels of peroxides, MOO is normally used without any pre-processing (Refining, Bleaching and Deodorization), which is mandatory for most of the commercial vegetable oils. As an example, soybean oil has dark red colour, beany flavour, canola oil has dark green colour with typical mustard smell and higher 
Table 1 Oil content of Moringa oleifera oil and some vegetable oils

\begin{tabular}{lll}
\hline Oil type & Oil content (\%) & Reference \\
\hline MOO & $38-42$ & {$[22]$} \\
SFO & $37-40$ & {$[52]$} \\
MKO & $13-15$ & {$[53]$} \\
CSO & $18-20$ & {$[54]$} \\
PKO & $46-50$ & {$[15]$} \\
CHO & $35-40$ & {$[55]$} \\
SBO & $18-20$ & {$[56]$} \\
WSO & $35-40$ & {$[54]$} \\
LSO & $40-42$ & {$[55]$} \\
\hline
\end{tabular}

MOO Moringa oleifera Oil, SFO Sunflower Oil, MKO Mango Kernel Oil, CSO Cottonseed Oil, PKO Palm Kernel Oil, CHO Chia Seed Oil, SBO Soybean Oil, WSO Watermelon Seed Oil, LSO Lemon Seed Oil

magnitudes of free fatty acids, phosphatides and other gross impurities, which must be removed to produce light coloured blend oils [10]. Oil processors treat free fatty acids and crude oil flavours as gross impurities and good quality edible oil should have lower concentration of these impurities. Substantial energy is required to convert crude oils into table oils. MOO has excellent oxidative and frying stability [11]. With $36.7 \%$ triolein was the major triglyceride, followed by palmito-diolein and stearodiolein (Table 4) [12]. Fatty acid composition of oil is almost similar to olive oil with oleic acid as the dominant fatty acid (75-77\%) [6]. Studies of Rahman et al. [13] evidenced that concentration of oleic acid in high oleic version of $\mathrm{MOO}$ was greater than $80 \%$, which was greater than olive oil. High oleic fraction of MOO can be regarded as functional food. Furthermore, studies have proved that diets rich in $\mathrm{C}_{18: 1}$ has the potential to lower the serum cholesterol and minimize the risk of cardiovascular diseases. Oils rich in monounsaturated fatty acids are getting a great deal of attention of food industry for having healthful properties and better oxidative stability.

Table 2 Fatty acid profile of Moringa oleifera oil and some vegetable oils

\begin{tabular}{|c|c|c|c|c|c|}
\hline Fatty acid & $\mathrm{MOO}$ & SBO & $\mathrm{CO}$ & SFO & $\mathrm{PO}$ \\
\hline$C_{12: 0}$ & -一 & -— & -— & 0.5 & 0.10 \\
\hline$C_{14: 0}$ & - - & 0.1 & -— & 0.2 & 1.24 \\
\hline$C_{16: 0}$ & 6.65 & 11 & 3.9 & 6.8 & 37.9 \\
\hline$C_{18: 0}$ & 2.82 & 4.0 & 1.9 & 4.7 & 4.11 \\
\hline$C_{18: 1}$ & 78.04 & 23.4 & 64.1 & 18.6 & 43.9 \\
\hline$C_{18: 2}$ & 4.16 & 53.2 & 18.7 & 68.2 & 13.4 \\
\hline$C_{18: 3}$ & - - & 7.8 & 9.2 & 0.5 & 0.45 \\
\hline$C_{20: 0}$ & 2.46 & 0.3 & 0.6 & 0.2 & 0.38 \\
\hline$C_{22: 0}$ & 5.84 & 0.1 & 0.2 & 一- & 一- \\
\hline Reference & {$[21,57]$} & [58] & [19] & [52] & [59] \\
\hline
\end{tabular}

Table 3 Comparison of chemical characteristics of Moringa oleifera oil with some vegetable oils

\begin{tabular}{lllllll}
\hline Parameter & MOO & SBO & CO & SFO & P. Olein & PO \\
\hline FFA \% & 0.16 & 0.88 & 0.35 & 0.31 & 0.08 & 0.08 \\
Moisture & 0.17 & 0.18 & 0.15 & 0.19 & 0.11 & 0.14 \\
${ }^{*}$ Colour & $1.0+10$ & $3.5+35$ & $3.2+33$ & $1.3+13$ & $1.2+12$ & $1.0+10$ \\
RI@40 ${ }^{\circ} \mathrm{C}$ & 1.452 & 1.467 & 1.462 & 1.473 & 1.457 & 1.452 \\
Sap. Value & 192 & 189 & 195 & 192 & 191 & 194 \\
USM & 1.28 & 1.21 & 1.24 & 1.31 & 0.67 & 0.62 \\
IV & 65.7 & 133.7 & 114.5 & 121.8 & 56.2 & 53.1 \\
PV & 0.24 & 1.8 & 1.5 & 2.34 & 0.27 & 0.21 \\
Reference & {$[4]$} & {$[56]$} & {$[52]$} & {$[60]$} & {$[15]$} & {$[15]$} \\
\hline
\end{tabular}

MOO Moringa oleifera Oil, FFA Free Fatty Acids, Sap. Value Saponification Value, USM Unsaponifiable Matter, IV lodine Value, PV Peroxide Value, SBO Soybean Oil CO: Canola Oil, SFO Sunflower Oil, P. Olein Palm Olein, PO Palm Oil *Lovibond Tintometer Scale (Red + Yellow) 1" Quartz Cell

MOO has a huge potential to become a commercial source of edible oil. However, promising features of MOO should be widespread. This work briefly describes the salient features of $\mathrm{MOO}$ as source of edible oil, for its probable use at commercial level. Proximate composition of Moringa oleifera seed revealed that the moisture content, crude protein, crude fat, ash content and nitrogen free extracts were $7.9,38.3,30.8,4.5,6.5$ and $16.5 \%$, respectively [7]. Oil content reported in this study was on the lower side while the studies of Anwar et al. [3] revealed that oil content of Moringa oleifera grown in temperate regions of Pakistan was $38-42 \%$.

Table 4 Triglyceride profile of Moringa oleifera oil and Virgin olive oil

\begin{tabular}{ll}
\hline Moringa oleifera oil & Virgin olive oil \\
\hline OOL & PPO \\
OOLn & PPL \\
POL & PSO \\
OOO & POO \\
POO + SOL & POL \\
OOGa & PLL \\
SOO & SSO \\
OLA & SOO \\
OOA & OOO \\
PPO & SOL \\
PPL & OOL \\
PSO & OLL \\
POB & OOLn \\
Reference [9] & LLL \\
& OLLn
\end{tabular}




\section{Commercial production status}

The situation of food insecurity is getting worst day by day, in future, feeding of ever increasing human population perhaps would be the most difficult task. On the other hand, resources of foods are drying. According to an estimate, about 2 billion humans will be added to the population of Asia and Africa [14]. In addition to other nutritional requirements, fats and oils must be consumed in sufficient concentration to fulfil the body's requirements [15]. Natures has gifted about 500,000 edible oil producing plants, it is worth mentioning that only 12 are being utilized for commercial production and processing. In view of the existing situation of food insecurity in the third world countries, new sources of edible oils must be discovered. Moringa oleifera (Drum Stick) is extensively grown in tropical and subtropical regions of Asia and Africa [8]. Soybean, sunflower, cottonseeds are the leading oilseeds. Oil content of soybean and cottonseed are about $18-20 \%$, with such moderate oil content. If soybean oil can become the leading source of edible oil, then how a plant (Moringa oleifera) with $40 \%$ good quality oil content cannot become the commercial source of edible oil. Moringa oleifera produces $3000 \mathrm{~kg}$ seed from 1 ha that can produce $1200 \mathrm{~kg}$ edible oil, as compared to soybean which produce $350-400 \mathrm{~kg}$ oil from 1 ha [6]. Due to lack of awareness, it is not commercially grown as an oilseed. India has adopted a wise strategy and started the commercial production of MOO, currently, 1.3 M. Ton of edible oil is annually extracted from the seeds of Moringa oleifera, with 380 $\mathrm{KM}^{2}$ area of production [16]. The cost of production of oil from Moringa oleifera is low as compared to other sources of edible oils, the unreferenced source revealed that cost of $1 \mathrm{~kg}$ seed is $0.15 \$$. In addition to low cost and higher oil content, oil has better functional properties over soybean, sunflower, canola, corn oils, they need partial hydrogenation for improved functional properties, whereas, MOO does not require partial hydrogenation. It can also be converted into olein and stearin fractions, which only have better functional properties but can also serve as superior alternates of partially hydrogenated fats. Further it contains about $5-6 \%$ behenic acid, which act as crystallizing agent [4]. In subcontinent, crystallized vanaspati is preferred over pasty stuff andapplication of MOO in vanaspati can improve its graininess and crystallization behaviour. Oil production potential of Moringa oleifera was assessed in arid climate of Chaco South Africa, on average basis; it produced $481.25 \mathrm{Kg}$ edible oil from one acre, desert conditions did not have significant effect on the seed production and oil content [17]. Commercial oilseeds require good quality soil with plenty of water, adequate fertilization and other expensive agronomic practices, whereas, Moringa tree can be grown in poor quality sandy, salt affected soils and it can resist long spells of drought with no effect on oil yield. The results of another investigation conducted in Argentina disclosed that Moringa oleifera trees produced $595 \mathrm{~kg}$ oil/acre in drought conditions [18].

\section{Food applications and antioxidant characteristics}

Anwar et al. [19] blended sunflower, canola and soybean oils with $\mathrm{MOO}$ at various concentrations, blending modified the physico-chemical characteristics of these oils. Fatty acid compositions of blends were different from the substrate oils; storage studies revealed that blends of sunflower, soybean, canola oils with MOO, generated lower concentration of primary and secondary oxidation products during the long term storage, with improved induction period. These results evidenced that MOO can be used for the enhancement of oxidative stability of commercial edible oils. Functional fat was prepared by blending MOO and butter oil. MOO was used up to $50 \%$ concentration and blends were then interesterified by sodium methoxide. Melting point of blend containing $50 \%$ butter oil and $50 \%$ MOO was $35.5{ }^{\circ} \mathrm{C}$, with considerable reduction in cholesterol. Results of storage and accelerated oxidation studies indicated that blends of butter oil with MOO were more resistant to oxidation [20]. The substantial antioxidant potential of MOO was utilized for the preservation of butter oil at ambient temperature; butter oil was blended with $\mathrm{MOO}$ from $2.5 \%$ to $10 \%$ concentration. Blending of butter oil with $\mathrm{MOO}$ enhanced $\mathrm{C}_{18: 1}$, free radical scavenging activity of blend containing $10 \%$ MOO was $31.65 \%$ as compare to $5.22 \%$ in butter oil. The total phenolic contents of blend containing $7.5 \% \mathrm{MOO}$ were $5.51 \mathrm{mgGAE} / \mathrm{g}$. In accelerated oxidation conditions, blends containing MOO offered more resistance to auto-oxidation. The concentration of conjugated dienes and trienes were significantly lower in the blends as compared to butter oil [21]. Suitability of MOO in the formulation of vanaspati was studied and MOO was incorporated into palm olein up to $75 \%$ level and blends were transesterified with $R h i$ zopus miehei. Blends were stored for 6 months and studied at 0,90 and 180 days of storage. Melting point of blend containing 50\% MOO was indifferent from market vanaspati with no harmful trans fatty acids. Concentration of $\mathrm{C}_{18: 1}$ was $56.7 \%$, when $50 \%$ MOO was added in the blend. MOO at all concentrations considerably improved the induction period, inhibited the oxidation of unsaturated fatty acids. A panel of trained judges was unable to find out any difference in the sensory characteristics of French fries prepared in vanaspati containing $50 \%$ MOO [22]. MOO has a melting point of $16-20{ }^{\circ} \mathrm{C}$, with these melting characteristics it cannot be used as salad oil. Rahamn et al. [13] fractionated MOO into olein and stearin fractions. Olein fraction was regarded as high oleic acid fraction (HOF). $\mathrm{C}_{18: 1}$ content of HOF 
was greater than olive oil; melting point of HOF was $1.2{ }^{\circ} \mathrm{C}$ with increased iodine value and lower cloud point. Oxidative stability of HOF in long term storage and accelerated oxidation was superior to sunflower, canola and soybean oils. MOO can replace the synthetic antioxidants for the long term preservation of butter oil at ambient temperature [21]. MOO oil was exposed to air to induce oxidation and oxidative stability of MOO was determined using peroxide value and specific extinctions at $232 \mathrm{~nm}$. After long term storage, MOO showed superior oxidative stability with lower levels of peroxides and specific extinctions measured at $232 \mathrm{~nm}$ [23]. Anwar and Bhangar [8] studied the antioxidant potential of MOO; they recorded the existence of higher magnitudes of antioxidants in MOO. MOO contains substantial amount of behenic acid (5.8 to 6.2\%), behenic acid is regarded as oil structuring and solidifying agent for potential application in margarine, shortenings without partial hydrogenation [24]. MOO was blended with palm olein, plam stearin and virgin coconut oil from 30 to $70 \%$ in the formulation of margarine, blending had major effects on solid fat index, melting behaviour, fatty acid, triglyceride profile. MOO improved the spreadability of margarine with zero trans isomers. MOO also enhanced the functional properties of palm stearin [25]. MOO oil contains zeatin, a potentially bioactive substance which is believed to have antioxidant and anti-inflammatory properties. It also contain beta-sitosterol, which blocks the biochemical events of cholesterol formation and possesses antiinflammatory perspective. MOO is also a rich source of kaempferol, which improves the metabolism and cell function, 36 natural antioxidants are naturally present in MOO [26]. The data regarding the presence of sterols (Table 5), tocopherols (Table 6) and total phenolic contents (Table 7) have been presented, respectively.

\section{Health benefits}

The demand and production of monounsaturated oils is mounting across the globe and large number of health benefits and superior oxidative stability of monounsaturated oils has increased their application in large number

Table 5 Sterols of Moringa oleifera oil and some vegetable oils $\mathrm{mg} / 100 \mathrm{~g}$

\begin{tabular}{lllll}
\hline Sterol & MOO & SBO & CO & SFO \\
\hline Campesterol & 15.81 & 68 & 10.29 & 9.28 \\
Stigma sterol & 23.10 & 64 & 7.51 & 0.18 \\
$\beta$-Sitosterol & 45.58 & 183 & 58.01 & 50.28 \\
$\Delta^{5}$ - Avenasterol & 8.46 & 5 & 1.26 & 1.11 \\
$\Delta^{7}-$ stigmasterol & Not Reported & 5 & 9.72 & 0.11 \\
$\Delta^{7}$ - Avenasterol & 0.53 & 2 & 5.54 & 0.06 \\
Reference & {$[23]$} & {$[62]$} & {$[63]$} & {$[63]$} \\
\hline
\end{tabular}

MOO Moringa oleifera Oil SBO: Soybean Oil CO: Canola Oil, SFO Sunflower Oil
Table 6 Tocopherol contents of Moringa oleifera oil and some vegetable oils

\begin{tabular}{|c|c|c|c|}
\hline Oil type & Tocopherol & Concentration mg/kg & Reference \\
\hline Moringa oleifera oil & $\begin{array}{l}\text { a-Tocopherol } \\
\text { Y-Tocopherol } \\
\delta \text {-Tocopherol }\end{array}$ & $\begin{array}{l}134.42 \\
93.7 \\
48.0\end{array}$ & [3] \\
\hline Virgin Olive Oil & 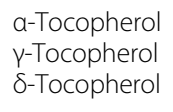 & $\begin{array}{l}88.50 \\
9.90 \\
1.60\end{array}$ & [23] \\
\hline Watermelon Seed Oil & $\begin{array}{l}\text { a-Tocopherol } \\
\text { Y-Tocopherol } \\
\delta \text {-Tocopherol }\end{array}$ & $\frac{127.49}{55.36}$ & {$[54]$} \\
\hline Mango Kernel Oil & $\begin{array}{l}\text { a-Tocopherol } \\
\text { Y-Tocopherol } \\
\delta \text {-Tocopherol }\end{array}$ & $\frac{205.44}{34.81}$ & {$[64]$} \\
\hline Soybean Oil & 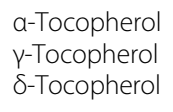 & $\begin{array}{l}9.3 \\
62.8 \\
26.7\end{array}$ & {$[65]$} \\
\hline Sunflower Oil & $\begin{array}{l}\text { a-Tocopherol } \\
\text { Y-Tocopherol } \\
\delta \text {-Tocopherol }\end{array}$ & $\begin{array}{l}613 \\
19 \\
--\end{array}$ & {$[66]$} \\
\hline Canola Oil & $\begin{array}{l}\text { a-Tocopherol } \\
\text { Y-Tocopherol } \\
\delta \text {-Tocopherol }\end{array}$ & $\begin{array}{l}226 \\
202 \\
3\end{array}$ & {$[67]$} \\
\hline Corn Oil & $\begin{array}{l}\text { a-Tocopherol } \\
\text { Y-Tocopherol } \\
\text { S-Tocopherol }\end{array}$ & $\begin{array}{l}134 \\
412 \\
39\end{array}$ & {$[54]$} \\
\hline
\end{tabular}

of foods [11]. Oleic acid (cis-9-octadecanoic acid) possesses a cholesterol lowering properties [27]. Olive oil, canola oil, peanut and rapeseed oil are regarded as the rich source of oleic acid, which varies from 50 to $80 \%$ [11]. Dietary guidelines suggest that oleic acid should be the part of regular diet to minimize the risk of cardiovascular diseases [28]. Concentration of oleic acid has been increased in some oilseeds through genetic modifications, e.g. high oleic acid sunflower oil and canola oil [11]. Monounsaturated oils do not require partial hydrogenation for better shelf stability. Consumption of partially hydrogenated fats has been correlated with the

Table 7 Total phenolic contents of Moringa oleifera oil, vegetable oils and extracts

\begin{tabular}{lcc}
\hline Oil type & TPC \% (GAE) & Reference \\
\hline Moringa oleifera oil & 7.1 & {$[21]$} \\
Chia Oil (Olein & 4.25 & {$[68]$} \\
Chia Oil (Stearin) & 2.57 & {$[68]$} \\
Almond Peel & 3.82 & {$[22]$} \\
Sesame Cake & 1.84 & {$[22]$} \\
Chia Seed Extract & 5.6 & {$[54]$} \\
Sugarcane Juice & 6.19 & {$[55]$} \\
Date Fruit Extract & 5.19 & {$[69]$} \\
Tamarind seed & 6.45 & {$[70]$} \\
\hline
\end{tabular}

TPC Total Phenolic Contents, GAE Gallic Acid Equivalent 
development of cardiovascular diseases [29]. High oleic acid fraction of MOO has been developed by enzymatic transesterification and fraction [4]. With greater than $80 \%$ oleic acid, high oleic acid fraction may be appropriately regarded as power house of oleic acid [13]. Oleic acid also act as a precursor of omega- 9 fatty acids, human body has the capability to convert $C_{18: 1}$ to omega- 9 fatty acids.

\section{Thermal stability}

A study was performed to investigate the frying stability of MOO, canola oil and sunflower oil. Frying test involved the frying of French fries for 6 days/ per, the total length of experiment was 6 days. Peroxide value, total polar compounds, conjugated dienes and trienes were used as indicators of oxidative deterioration. After 6 heating cycles (each cycle $6 \mathrm{~h}$ ) peroxide value of canola oil and soybean oil was considerably higher than MOO. The rate of darkening and increase in viscosity in canola and soybean oils were substantially higher than MOO. The concentrations of total polar compounds were the lowest in MOO [4]. Anwar et al. [19] also reported that the concentration of polymers in MOO after repeated heating cycles were lower than soybean, canola and sunflower oils. Generation of polymers is a serious problem which not only reduces the nutritional quality of frying media but also has a bad impact on sensory attributes of fried goods. Melting point of moringa oleifera is similar to palm olein. Currently, potato chips frying industry is mainly concentrating on palm olein as frying stuff. $\mathrm{MOO}$ with great frying stability can be a used as an alternate of palm olein for the frying industry. Nadeem et al. [22] studied the sensory characteristics of French fries prepared in MOO and palm olein blends, sensorial perspectives of French fries were not different to commercially used fat. Oxidative stability of soybean, sunflower and canola oils was compared with high oleic acid fraction of MOO [13]. After 5 days in an oven (63 ${ }^{\circ}$ $\mathrm{C}$ ), peroxide values of sunflower, soybean and canola oils were greater than high oleic acid fraction of MOO [13]. The superior oxidative stability of MOO in accelerated oxidation conditions is also reported in literature (Table 8 ) [20, 21]. The higher oxidative stability of MOO during deep frying has been reported [5]. Oxidative stability of cold pressed MOO was compared with raw and groundnut oil, concentration of free fatty acids, peroxides and oxidation products was lower in MOO than raw and refined groundnut oil [30]. Frying performance of $\mathrm{MOO}$ was assessed in repeated frying process for 5 days at $175{ }^{\circ} \mathrm{C}$ and $\mathrm{MOO}$ revealed excellent frying stability, generation of lower amounts of free fatty acids, peroxides, extinction coefficients at $232 \mathrm{~nm}$ with minimum decline in flavour score [5].
Table 8 Induction period of Moringa oleifera oil and some vegetable oils

\begin{tabular}{lll}
\hline Oil Type & Induction period (Hours) & Reference \\
\hline MOO & 42.56 after degumming & {$[23]$} \\
MOO & 72.56 crude oil & {$[23]$} \\
PO & 10.4 & {$[52]$} \\
SBO & 4.27 & {$[56]$} \\
CO & 5.84 & {$[19]$} \\
SFO & 3.51 & {$[19]$} \\
WSO & 3.82 & {$[54]$} \\
CHO & 1.32 & {$[71]$} \\
WSO & 4.1 & {$[54]$} \\
\hline
\end{tabular}

MOO Moringa oleifera Oil SFO: Sunflower Oil MKO: Mango Kernel Oil, CSO Cottonseed Oil, CHO Chia Seed Oil, SBO Soybean Oil, WSO Watermelon Seed Oil, LSO Lemon Seed Oil

\section{Cholesterol contents}

Cholesterol is a steroid, waxy metabolite, belongs to the unsaponifiable matter of lipids. It is insoluble in the aqueous/watery phase of blood, transported in the body through specialized proteins to various parts of the body [31]. LDL carries cholesterol from liver to the peripheral tissues, LDL has been designated as bad cholesterol, high density lipoproteins (HDL) transport cholesterol back from the peripheral tissues to the liver and regarded as beneficial cholesterol [32]. The ratios of LDL to HDL, concentration of total cholesterol, LDL and triglycerides exceeding 5, 200, 150 and 150 and HDL lower than $35 \mathrm{mg} / \mathrm{dL}$, respectively is associated with enhanced risk of cardiovascular disease. Intake of dietary cholesterol should not exceed $300 \mathrm{mg} /$ day [33]. Dairy products e.g. cheese, cream, butter, butter oil etc. For example, 219, 110, $105 \mathrm{mg} / 100 \mathrm{~g}$ cholesterol is present in butter, cheese and ice cream, respectively [34]. MOO does not cholesterol, blending of butter oil with MOO significantly decreased the concentration of dietary cholesterol [20].

\section{Fractionation}

Rahamn et al. [13] fractionated MOO into olein and stearin fractions through dry crystallization technique, fatty acid composition of olein fraction revealed the magnitude of oleic acid of oleic acid was greater than $80 \%$. The effect of MOO on the crystallization behaviour of palm oil was investigated and MOO was incorporated into palm oil at $20 \%$ concentration. Fractionation was performed by solvent and dry crystallization techniques at 18 and $21{ }^{\circ} \mathrm{C}$ and the yield of olein fraction obtained via solvent fractionation was greater than dry crystallization. GC analysis of the liquid fractions revealed that the intensification of oleic acid and triolein. Remarkable differences were noted in the melting characteristics of olein and stearin fractions obtained by two different fractionation methods. MOO stearin has higher melting point and may 
be used as an alternated of chocolate fat/confectionary fat and bakery shortening, however, theses aspects needs intensive research work [35]. After the rearrangement of esters, melting point of $\mathrm{MOO}$ increased from $19.8{ }^{\circ} \mathrm{C}$ to $35.2{ }^{\circ} \mathrm{C}[20]$. MOO was transesterified with lipases meihei followed by fractionation. Fatty acid composition, solid fat index of olein and stearin fraction was considerably different from the parent MOO, olein fraction remained clear at $2{ }^{\circ} \mathrm{C}$, with no haziness, offering a great perspective for usage as salad/oil/cooking oil/mayonnaise oil etc. [4].

\section{Medicinal and nutraceutical action}

MOO is primarily a high oleic version of essential/ edible oil, oleic acid possesses anti-inflammatory characteristics, prevents cardiovascular diseases and breast cancer (Table 9) [36]. Oil is a rich source of vitamin A, and E, with strong antibacterial properties and it confers softness and smoothness to dry and tuff skin. It also possesses antihypertensive, antifungal and antiepileptic characteristics [37]. It can be used in many types of soaps, for the treatment of rheumatism, gout and venomous bites [38]. Strong antioxidant activity of $\mathrm{MOO}$ oil can be utilized in the formulation of body cream with increased antioxidant activity, antibacterial activity, better inhibition of free radicals, smooth and soft skin [39]. MOO has been used in the preparation of folk medicines in many civilizations since pre-historic time. The therapeutic perspectives of MOO has been documented in literature and it has antiseptic and antiinflammatory, anti-rash characteristics, cures insect bites, burns and cuts, fights black heads, acne, counterfeiting the bad effects of pollution of skin, maintain natural glow of the skin, scalp moisture, improves the strength of hairs, act as antidandruff and prevent split ends, unlike other vegetable oils. It is great source of vitamin $\mathrm{C}$, which prevent scurvy and possesses many other health benefits and it has the capability of lowering hypertension and persuade good sleep, guards bones and calms the nervous system. MOO has been the part of skin ointments, skin moisturizing agent and other skin cosmetics since the Egyptian times [40, 41]. Efficacy of lovastatin and Moringa oleifera were compared and study trial was conducted on rabbits. Feed was supplemented with $6 \mathrm{mg} / \mathrm{kg} /$ day and $200 \mathrm{mg} / \mathrm{kg} /$ day. After the experimentation period of 120 days, it was observed that both Moringa oleifera and lovastatin reduced

Table 9 Therapeutic Perspectives of Moringa oleifera oil

\begin{tabular}{ll}
\hline Medical Disorder & Reference \\
\hline Fungus induced infections & {$[5]$} \\
Pyodermia (Skin Disease) & {$[72]$} \\
Laxative & {$[49]$} \\
Improved prostate function, Scurvy, & {$[49]$} \\
Gout and bladder function & {$[21]$} \\
Antioxidant & \\
\hline
\end{tabular}

the serum cholesterol, phospholipids, triglycerides, VLDL and LDL cholesterol. Rabbits fed on Moringa oleifera supplemented diet showed less fat in liver, heart and aorta. Faecal analysis revealed that concentration of cholesterol in the faces of Moringa supplemented diet was higher than control group (which did not receive Moringa supplemented diet) [42].

\section{Toxicological evaluation}

The impact of MOO centred feed on growth performance, packed cell volume, haemoglobin, white blood cells, monocytes, lipid profile, urea, creatine were determined in albino rats. Three weeks old, 12 albino rats were randomly stratified in two groups, each group was comprised of 6 rats, the average weight ranged from 31.6 to $35 \mathrm{~g}$. The group of rats fed on soybean oil was used as control, while, the second group was fed on MOO, experiment lasted for six weeks. After six weeks, blood samples of both the groups were tested for total cholesterol, high density lipoprotein, low density lipoprotein, triglyceride. Body weight, creatine, urea concentration and haematological parameters of both the groups were not significantly different. These results evidenced that MOO improved the growth performance and had a positive immune stimulatory impact on the growth of albino rats, with neutraceutical effect and no risk of cardiovascular disease [43].

\section{Biodiesel production}

Moringa seeds produce $30-40 \%$ good quality oil, which is high in oleic acid. The quality of MOO is superior to sunflower oil and scientific evidences have shown that biodiesel prepared from MOO was superior to biodiesel made from other substrates [44]. The methyl esters of biodiesel prepared from MOO was 67, which is the highest for a biodiesel fuel. About 20001 biodiesel can be produced from one hectare and production of biodiesel can be started after one year of the plantation, as tree bears fruit within one year of the cultivation [45]. The biodiesel derived from MOO has higher iodine value as compared to conventional diesel fuels, which indicates that MOO based biodiesel has better stability [46]. With higher octane number, it has higher ignition performance and cold filter plugging point, showing better ignition performance in winter as well. The recovery and quality of biodiesel from $\mathrm{MOO}$ is higher as compared to other crops with the recovery of top grade glycerine as by-product. MOO is a better sustainable source of biodiesel than other plants e.g. Jatropha, as Moringa is cultivated primarily for food [47, 48]. 30 days old Moringa plants were milled to mesh size 5 , followed by the separation of liquid fraction from solid mass through filtration. The liquid was transferred to gas reactor. $1 \mathrm{~kg}$ volatile solids produced $580 \mathrm{~L}$ of gas, with $81 \%$ methane content [49]. 


\section{Personal care formulations}

The major fatty acid in MOO is oleic acid, which is widely recommended in the preparation of pharmaceutical ointments. It has high cosmetic value, helps to remove dirt from the skin and is considered as superb cleansing agent. It has non-drying characteristics, can be easily blended with other essential oils; these properties make moringa oil as excellent massage oil. Oil can be used in the preparation of different types of soaps, cosmetic cream and lip balm. MOO based soaps has stable lather with better cleansing perspectives [50]. MOO has been the part of folk medicines since thousands of years; oil was used as perfume and skin lotion by the Egyptian, Roman and Greek communities [51]. Egyptians used MOO in the treatment of skin disorders, as smoothing, moisturizing and oiling agent for the treatment of dry skin and therapeutic massages. It has the capability of absorbing and retaining the flavouring compounds [40]. Currently MOO is widely used in the formulations of body creams, lotions, balms, scrubs and anti-hair fall formulations. In cosmetics, it is preferred over other oil as it does not leave greasy after feel [24].

\section{Conclusions}

MOO can be sued in the formulation of vanaspati, margarine, bakery shortening, salad oil, cooking oil, frying of potato chips, frying fats in industry and restaurants while stearin fractions can be used as bakery fat.

\section{Acknowledgement}

The authors are highly obliged to the Library Department, Government College University Faisalabad (GCUF), University of Veterinary and Animal Sciences (UVAS) and IT Department, Higher Education Commission (HEC, Islamabad) for access to journals, books and valuable database.

\section{Funding}

Not Applicable.

\section{Availability of data and materials}

The dataset supporting the conclusions of this article is included within the article.

\section{Authors' contributions}

MN conceptualized, provided the technical assistance and guided in the data collection. MI helped for drafting the manuscript. "It's also confirmed that all the authors read and approved the final manuscript".

\section{Competing interests}

The authors declare that they have no competing interests.

\section{Consent for publication}

Not Applicable.

\section{Ethics approval and consent to participate}

Not Applicable.

\section{Author details}

'Department of Dairy Technology, University of Veterinary and Animal Sciences, Lahore, Pakistan. ${ }^{2}$ Institute of Home and Food Sciences, Faculty of Science and Technology, Government College University, Faisalabad, Pakistan.
Received: 1 November 2016 Accepted: 17 November 2016

Published online: 08 December 2016

\section{References}

1. Potter NW, Hotchkis J. Food Science. 5th edition. New York: AVI Publishing Co. Inc; 1998. p. 264

2. Campbell-Platt G. Food Science and Technology. West Sussex: Wiley-Blackwell; 2009. p. 520.

3. Anwar F, Bhanger Ml, Yasmeen S. Antioxidant activity of some natural extracts in corn oil. In: Murata N, Yamada M, Nishida I, Okuyama H, Sekiya J, Hajime W, editors. Advanced research of plant lipids. Netherlands: Kluwer Publishers; 2003. p. 24

4. Abdulkarim SM, Lai OM, Muhammad SKS, Long K, Ghazali HM. Oleic acid enhancement of Moringa oleifera seed oil by enzymatic transesterification and fractionation. Asean Food J. 2007:14:91-102.

5. Lalas S, Tsaknis J. Extraction and identification of natural antioxidants from the seeds of Moringa oleifera tree variety of Malavi. J Am Oil Chem Soc. 2002;79:677-83

6. Mohammed AS, LAI OM, Muhammad SKS, Long K, Ghazali HM. Moringa oleifera, Potentially a New Source of Oleic Acid-type Oil for Malaysia. Investing in innovation.

7. Siddhuraju P, Becker K. Antioxidant properties of various solvent extracts of total phenolic constituents from three different agro climatic origins of drumstick tree (Moringa oleifera Lam). J Agri Food Chem. 2003:54:2144-55.

8. Anwar F, Bhanger MI. Analytical characterization of Moringa oleifera seed oil grown in temperate regions of Pakistan. J Agr Food Chem. 2003:51:6558-63.

9. Abdulkarim SM, Long K, Lai OM, Muhammad SKS, Ghazali HM. Some physico-chemical properties of Moringa oleifera seed oil extracted using solvent and aqueous enzymatic method. Food Chem. 2005;93:253-63.

10. Abdulkarim SM, Long K, Lai OM, Muhammad SKS, Ghazali HM. Use of enzymes to enhance oil recovery during aqueous extraction of Moringa oleifera seed oil. J Food Lipids. 2006;13:113-30.

11. Corbett P. It is time for an oil change! Opportunities for high-oleic vegetables oils. Inform. 2003;14:480-1

12. Vlahov G, Chepkwony PK, Ndalut PK. NMR characterization of triacylglycerols of Moringa oleifera seed oil: an "oleic-vaccenic acid" oil. J Agric Food Chem. 2002:50:970-5.

13. Rahman F, Nadeem M, Azeem MW, Zahoor Y. Comparison of the chemical characteristics of high oleic fraction of Moringa oleifera oil with some vegetable oils. Pak J Anal Environ Chem. 2014;15:80-3.

14. FAO. The state of food insecurity in the world. 2015. Retrieved from http:// www.fao.org/3/a-i4646e.pdf. Accessed on 8 June 2016

15. O'Brien RD. Fats and oils: formulating and processing for applications. 3rd edition. Boca Raton: CRC Press; 2008. p. 143

16. Rajangam J, Azahakia Manavalan RS, Thangaraj T, Vijayakumar A, Muthukrishan N. Status of production and utilisation of moringa in southern India. 2001. www.moringanews.org/actes/rajangam_en.doc. Accessed on 15 Apr 2014.

17. Ayerza R. Seed and oil yields of Moringa oleifera variety Periyakalum-1 introduced for oil production in four ecosystems of South America. Industrial Crops Prod. 2012;36:70-3.

18. Ayerza R. Seed's yield components, oil content, and fatty acid composition of two populations of moringa (Moringa oleifera Lam.) growing in the Arid Chaco of Argentina. Ind Crops Prod. 2011;33:389-94.

19. Anwar F, Qayyum HMA, Hussain Al, labal S. Antioxidant activity of 100 and $80 \%$ methanol extracts from barley seeds (Hordeum vulgare L.): stabilization of sunflower oil. Grasas y Aceit. 2010;61:237-43.

20. Nadeem M, Abdullah M, Javid A, Mahmood T. Evaluation of functional Fat from interesterified blends of butter oil and Moringa oleifera oil. Pak J Nutr. 2012;11:725-9

21. Nadeem M, Hussain I, Abdullah M. Improvement of the oxidative Stability of Butter Oil by Blending with Moringa oleifera Oil. J Food Proc Preserv. 2013; doi:10.1111/jfpp.12108

22. Nadeem M, Situ C, Mahmud A, Khalique A, Imran M, Rahman F, Khan S. The effect of sesame (Sesamum indicum L.) cake extract for oxidative stabilization of olein based butter. J Am Oil Chem Soc. 2014; doi:10.1007/ s11746-014-2432-3.

23. Tsaknis J, Lalas S, Gergis V, Dourtoglou V, Spiliotis V. A total characterization of Moringa oleifera Malawi seed oil. Riv Ital Sostanza Grasse. 1998;75:21-7.

24. Warra AA Cosmetic potentials of African Shea nut (vitellaria paradoxa) butter. Curr Res Chem. 2011;3:80-6. 
25. Dollah S, Abdulkarim SM, Ahmad SH, Khoramnia AK, Ghazali MH. Physicochemical properties and potential food applications of Moringa oleifera seed oil blended with other vegetable oils. Journal of Oleo Sci. 2014;DOI: 10. 5650/JOS.ess 13235

26. Kumar NA, Pari L. Antioxidant action of moringa oleifera lam. (drumstick) against antitubercular drugs induced lipid peroxidation in rats. J Med Food. 2003;6:255-9.

27. Lokuruka MNI. Role of fatty acids of milk and dairy products in cardiovascular diseases: a review. Afr. J Food Agri Nutr Dev. 2007;7(1):45-59.

28. Lee $\mathrm{YW}$, Kim JD, Zheng J, Row KH. Comparisons of isoflavones from Korean and Chinese soybean and processed products. J Biochem Eng. 2007;36:49-53.

29. Mensink RP, Katan MB. Effect of dietary trans-fatty acids on high-density and low-density lipoprotein cholesterol levels in healthy subjects. J Clinical Nutr. 1990;323:439-45

30. Ogunsina BS, Indira TN, Bhatnagar AS, Radha C, Debnath S, Gopala Krishna AG Quality characteristics and stability of Moringa oleifera seed oil of Indian origin. J Food Sci Technol. 2011:51(3):503-10. doi:10.1007/s13197-011-0519-5.

31. Jensen RG. Fatty acids in milk and dairy products. In: Chow CK, editor. Fatty acids in foods and their health implications. 2nd ed. New York and Basel: Marcel Dekker; 2002. p. 109-24.

32. American Heart Association. Heart and stroke encyclopedia. Dietary guidelines for healthy American adults. 2008. Retrieved from http://www. americanheart.org. Accessed on 30 Aug 2015.

33. American Heart Association. Heart Disease and stroke. You are the cure. Washington, USA; 2009. Found at: http://www.americanheart.org/.

34. Kwak HS, Ahn J. Optimization cholesterol removal in cream using beta cyclodextrin response surface methodology. J Food Sci. 1999;64:629-32.

35. Marikkar JMN, Ghazali HM. Effect of Moringa oleifera oil blending on fractiona crystallization behavior of palm oil. Int J Food Prop. 2011;14(5):1049-59.

36. Pauwels EK. The protective effect of the Mediterranean diet. Focus on cancer and cardiovascular risk. Med Princ Pract. 2011;20(2):103-11.

37. Singha R. Advantages of moringa oil. Retrieved from www.buzzle.com/ articles/moringa oil.html. Accessed on 30 Dec 2010.

38. Parrotta JA. Healing plants of peninsular India. Wallingford and New York: Cabl Publishing; 2001.

39. Ojiako EN, Okeke CC. Determination of antioxidant of Moringa oleifera seed oil and its use in the production of a body cream. Asian J Plant Sci Res. 2013;3:1-4.

40. Fuglie $\amalg$. New Uses of Moringa Studied in Nicaragua. ECHO Development Notes \#68. 2000

41. Monica GM. Miracle Tree, KOS Health Publications. 2005.p. 91

42. Mehta LK, Balaraman R, Amin AH, Bafna PA, Gulati OD. Effect of fruits of Moringa oleifera on the lipid profile of normal and hypercholesterolaemic rabbits. J Ethnopharmacol. 2003;86:191-5.

43. Bolanle $\mathrm{AO}$, Olufunmilayo $\mathrm{A}$, Olorunfemi $\mathrm{O}$, Temitayo $\mathrm{O}$. The effect of Moringa oleifera oil - based diet on growth performance, ematological parameters and plasma lipid profile in albino rats. World J Pharm Pharm Sci. 2014;3:121-130.

44. Umer R, Anwar F, Moser BR, Knothe G. Moringa oleifera oil: a possible source of biodiesel. Bioresource Technol. 2008;99:8175-9.

45. Brockman H. Production of biodiesel from perennials. Government of Western Australia: Department of Agric and Food; 2008.

46. Anonymous. Moringa's hope-the miracle tree. 2012. Available at: http:// moringashope.blogspot.com/2012/03/moringa-oil-asbiofuel-is-better-than. html (Accessed on 12 May 2012).

47. Kywe T, Oo MM. Production of biodiesel from jatropha oil (Jatropha curcas) in pilot plant. World Acad Sci Eng Technol. 2009;50:477-83.

48. Parawira W. Biodiesel production from Jatropha curcas: a review. Sci Res Essay. 2010;5:1796-808.

49. Fuglie $\sqcup$. The miracle tree: moringa oleifera: natural nutrition for the tropics. Training manual. Dakar: Church World Service; 2001.

50. Mehta J, Shukla A, Bukhariya V, Charde R. The magic remedy of Moringa oliferia: an overview. Int J Biomed Adv Res. 2011;2:215-27.

51. Kale S, Megha G. Formulation and in vitro evaluation for sun protection factor of Moringa oleifera Lam (family-moringaceae) oil sunscreen cream. Int J Pharm Pharm Sci. 2011:3:371-5.

52. Shahidi F. Bailey's industrial edible oil and fat products. 6th ed. NY: Willey; 2005. p. 174

53. Kittiphoom S, Sutasinee S. Mango seed kernel oil and its physicochemical properties. Int Food Res J. 2013;20(3):1145-9.
54. Azeem W, Nadeem M, Sajid R. Analytical characterization of pure and blended watermelon (Citrullus lanatus) oil: impact of blending on oxidative stability. Pak J Analytical Environ Chem. 2015;16:52-8.

55. Ullah R, Nadeem M, Ayaz M, Imran M, Tayyab M. Fractionation of chia oil for enrichment of omega 3 and 6 fatty acids and oxidative stability of fractions. Food Sci and Biotechnol. 2016;25:41-7. doi:10.1007/s10068-016-0006-x.

56. Erickson DR. Practical handbook of soybean processing and utilization. Champaign: AOCS press; 1995. p. 146

57. Anwar F, Latif S, Ashraf M, Gilani AH. Moringa oleifera: a food plant with multiple medicinal uses. Phytotherapy Res. 2007;21:17-25.

58. De Greyt W, Kellens K. In: Hamm W, Hamilton RJ, editors. Refining practice in edible oil processing. Sheffield: Sheffield Academic Press; 2000. p. 79-128.

59. O'Brien RD, Wakelyn PJ. Cottonseed oil: an oil for trans free options. Food Technol. 2005;16:677-9.

60. Anwar F, Hussain Al, lqbal S, Bhanger MI. Enhancement of the oxidative stability of some vegetable oils by blending with Moringa oleifera oil. Food Chem. 2007:103:1181-91.

61. Andrikopoulos NK, Tzamtzis VA, Giannopoulos GA, Kalantzopoulos GK, Demopoulos CA. Deterioration of some vegetable oils. I. During heating or frying of several foods. Rev Fr Corps Gras. 1989;36:127-9.

62. Vlahkis C, Hazebroek J. Phytosterol accumulation in canola, sunflower and soybean oils: effect of genetics, planting location and temperature. J Am Oil Chem Soc. 2000;76:1313-21.

63. Bohacenko I, Kopicova Z. Detection of olive oils authenticity by determination of their sterol content using LG/GC. Czech J Food Sci. 2001;3:97-103.

64. Mostafa UES. Phenolic compounds and antioxidant potential of mango peels and kernels (Mangifera indica L.) on the frying oil stability, lipid profile activity of some antioxidant serum enzymes in rats. J Am Sci. 2013:9(11):371-78.

65. Connor WE. Importance of n-3 fatty acids in health and disease. Amr J Clinical Nutr. 2000;71:171S-5S.

66. National Sunflower Association. The sunflower, National Sunflower Association, Bismarck, N. Dakota. 2001; March/ April 2001. Page 8-9

67. Gertz C, Klostermann S, Kochhar SP. Testing and comparative oxidative stability of vegetable fats and oils at frying temperature. European J Lipid Sci and Tech. 2000:102:534-51.

68. Ullah R, Nadeem M, Ayaz M, Imran M, Tayyab M. Fractionation of chia oil for enrichment of omega 3 and 6 fatty acids and oxidative stability of fractions. J Food Sci and Biotech. 2016;25:41-7.

69. Rahman F, Nadeem M, Khan S, Ahmad S, Zahoor Y. Antioxidant activity of date palm fruit (phoenix dactylifera L.) extract for oxidative stabilization of butter oil at ambient temperature. Pak J Scienti Ind Res. 2015;58:59-64.

70. Soong YY, Barlow PJ, Perera CO. A Cocktail of phytonutrients: identification of polyphenols, phytosterol and tocopherols from mango seed kernel. IFT Annual meeting, July 12-16, Las vegas, USA; 2004.

71. Imran M, Nadeem M, Manzoor MF, Javed A, Ali Z, Muhammad N, Akhtar M, Ali M, Hussain Y. Fatty Acids Characterization, Oxidative Perspectives and Consumer Acceptability of Oil Extracted from Pre-treated Chia (Salvia hispanica L.) Seeds. Lipids Health Dis. 2016; DOI: 10.1186/s12944-016-0329-x.

72. Foidl N, Makkar HPS, Becker K. The potential of Moringa oleifera for agricultural and industrial uses. In: Fuglie LJ, editor. The Miracle Tree: The Multiple Attributes of Moringa. Dakar: Church World Service; 2001. p. 45-76.

\section{Submit your next manuscript to BioMed Central and we will help you at every step:}

- We accept pre-submission inquiries

- Our selector tool helps you to find the most relevant journal

- We provide round the clock customer support

- Convenient online submission

- Thorough peer review

- Inclusion in PubMed and all major indexing services

- Maximum visibility for your research

Submit your manuscript at www.biomedcentral.com/submit 